\title{
Development and Cost Economics of Chicken Powder Incorporated Shelf Stable Fried Snack Prepared from Spent Hen Meat with Rosemary and Betel Leaves Extract
}

\author{
Ashish Saini ${ }^{1 *}$, Anurag Pandey ${ }^{1}$, Sanjita Sharma ${ }^{2}$, Priyanka Meena ${ }^{1}$, \\ Asman Singh Gurjar' ${ }^{1}$ and Ravi Raman ${ }^{1}$
}

${ }^{1}$ Department of Livestock Products Technology, ${ }^{2}$ Department of Livestock Production Management, Post Graduate Institute of Veterinary Education and Research, Jaipur-302031, India

*Corresponding author

\begin{abstract}
A B S T R A C T
Keywords

Break-even point, Cost benefits ratio, Fried snack and net profit

Article Info

Accepted:

17 January 2018

Available Online:

10 February 2018

The purpose of the study was undertaken to standardize processing protocol of fried snack and to evaluate economics of the developed product. Three treatments were prepared with incorporation of rosemary extract $\left(\mathrm{T}_{1}\right)$, betel extract $\left(\mathrm{T}_{2}\right)$ and their $1: 1$ combination $\left(\mathrm{T}_{3}\right)$ in product by replacing amount $(3 \%)$ of chicken powder from formulation to evaluate economics of the fried snack. All treatments and control group were deep fried at $190^{\circ} \mathrm{C}$ for $45 \mathrm{sec}$. to make the product. In the cost economics, cost of formulation was found highest for group $\mathrm{T}_{2}$. Maximum total net profit was found for control followed by $\mathrm{T}_{2}, \mathrm{~T}_{4}$ and $\mathrm{T}_{1}$. The break-even point was estimated as ₹ $14,31,707.37$ for control while ₹ $24,96,454.21$, ₹ $16,33,154.67$ and $21,88,047.71$ for $T_{1}, T_{2}$ and $T_{3}$ respectively. The cost benefits ratio was found highest for control and $\mathrm{T}_{3}$ whereas lowest for $\mathrm{T}_{1}$. The estimated details of economics of the developed product concluded that a viable enterprise can be established by keeping rate ₹ 261, ₹ 241, ₹ 260 and ₹ 230 for rosemary extract, betel extract, their 1:1 combination incorporated product and control respectively.

\section{Introduction}

The poultry industry in India plays a foremost success story. Poultry population in India is around 729.21 million and it contributes $45 \%$ of total meat production in India (BAHS, 2014).

Poultry industry, a vibrant and organized sector, play a key role in ensuring quality animal proteins at cheaper rate particularly

through spent hen meat in India (FAO, 2006). Spent hen meat is high in fat and cholesterol content, less tender, less juicy and poor in functional characteristics due to increased cross linking in collagen, resulting in lower remunerative prices as compared to broiler meat. By standardizing appropriate and economic technology for processing, such underutilized meat may be converted into value-added meat products that are palatable and economically viable (Kumar et al., 2015).
\end{abstract}


In India, snacks has been connected with social customs and been developed into culinary art; it is used as an accompaniment to meal, as a snack and croutons in soups (Talukder et al., 2015). In the newly emerging era of fast and convenience foods, ready to eat foods are becoming increasingly popular. Traditional foods, particularly the snack foods are integral parts of food matrix, which have sustained the culinary heritage, cultural identity and shared values of people for many generations. Due to their nutritive and sensory qualities, a broad range of traditional food products from plant origins like bhujia are still consumed today and sold under various geographical indications. Bhujia is gram flour based, deep fried, shelf stable ready to eat salted snack with an opportunity to incorporate meat powder in its formulation.

Diversity of convenience/ready-to-cook/readyto-serve chicken meat products such as kababs, tikkas, lollipops, fingers, nuggets, patties and sausages exist in the markets. Perishability of meat products has been regarded as a very serious problem, particularly in tropical countries like India, where household refrigeration facility is scanty (Kumar et al., 2015). In the present era, the energy demand for food preservation and improving the safety of preserved foods vis-àvis convenience, development of shelf stable products is highly desirable. The most common form of deterioration in shelf stable meat products is; oxidative rancidity, it's ranging from extensive flavor changes, color losses and structural damage to proteins leads to "loss of freshness" that discourages repeat purchases by consumers. The most efficient and practical way to prevent oxidative of meat products is to incorporate antioxidants into formulations. Antioxidants either synthetic or natural have become an indispensable group of food additives mainly because of their unique properties of enhancing the shelf life of food products without any damage to sensory or nutritional qualities (Nanditha and Prabhasankar, 2008). In industrial processing, mainly synthetic antioxidants such as butylated hydroxylanisole (BHA) and butylated hydroxyltoluene (BHT) are used to prolong the storage stability of meat products. However, increasing concerns over the safety of synthetic food additives has resulted in a trend towards "natural products". Natural antioxidants extracted from herbs and spices exhibit various degrees of efficacy when used in different food applications (Bowser et al., 2014). Among natural antioxidant sources, rosemary (Rosmarinus officinalis L.) and its extract used as an antioxidant in different chicken meat products like frankfurters (Rinzar et al., 2006) and patties (Naveena et al., 2013). Further, betel (Piper betel) and its extract have been used in different food systems; however, reports of its use in meat products are very scanty.

Thus, the present study was undertaken to develop and literal economization of preparation cost of product from spent hen meat incorporated with rosemary and betel leaves extract.

\section{Materials and Methods}

Spent hen required for the experiments was obtained from local market and deboning was done manually in the laboratory. After the removal of the separable tissue and fat, meat was packed in colorless polyethylene bags and stored over-night at $4^{\circ} \mathrm{C}$ in a refrigerator for conditioning and later on frozen at $-18 \pm 1{ }^{\circ} \mathrm{C}$ for the subsequent use. Frozen meat was thawed at $4 \pm 1^{\circ} \mathrm{C}$ for $24 \mathrm{hrs}$ before use and cut into small pieces before grinding in a meat grinder.

Gram flour, refined oil, common salt and spices used in product formulation were procured from the local market. After removal of extraneous matter, all the spice ingredients 
were dried in an oven at $50^{\circ} \mathrm{C}$ for $2-3 \mathrm{hrs}$. The ingredients were ground in a grinder with a suitable blade and sieved through a fine mesh. The moisture content analyzed every hour until stable moisture content was obtained. Spice mix so obtained was incorporated into product formulations.

\section{Methodology for preparation of product}

The deboned frozen lean spent hen meat cubes were ground through $8 \mathrm{~mm}$ plate, followed by $4 \mathrm{~mm}$ plate in meat mincer (Nova Pvt. Ltd.). After mincing, meat was boiled in pressure cooker at $120^{\circ} \mathrm{C}$ for $15 \mathrm{~min}$. The minced and pressure cooked chicken meat was dried in hot air oven for preparation of chicken powder at a temperature of $80^{\circ} \mathrm{C}$ for $9 \mathrm{hrs}$. The chicken powder, gram flour, spice mix, table salt and $3 \%$ level of herbal (rosemary, betel and 1:1 combination of both herbs) extract were incorporated in final mix. Subsequently, the chicken broth was added to make the dough at approx. 40 per cent of the formulation and kept it for 10-15 min for conditioning.

Later on, the dough was filled in the vermicelli maker machine and the product was deep fried for $45 \mathrm{sec}$ at the temperature of $190^{\circ} \mathrm{C}$ for the preparation of product.

For the storage study herbal treated as well as control product stored up to two months at room temperature for physicochemical, microbiological and sensory evaluation.

Formulas used in the estimation of the economics of product as fallow

Cost of production for $100 \mathrm{Kg}$ product $=$ Cost of formulation + cost of overhead production

Cost of overhead production = Daily depreciation cost + Rent of building + Labour cost+ Cost of electricity + Maintenance cost + Water charge + Cost of packaging
Cost for $1 \mathrm{~kg}$ product $=($ Production cost of $100 \mathrm{Kg}$ formulation/ \% cooking yield)

Income $=$ total sale price - total cost of production

Break-Even point $=$ Fixed cost $\times$ Total sales/Total sales - Variable cost

Cost-benefit ratio $=$ Total profit $/$ Total cost of production

Net profit/day $=$ Total profit- amount of loan payment/day

\section{Results and Discussion}

The total cost of formulation for spice mix. was calculated ₹ $395.05 / \mathrm{kg}$ are mentioned in the Table 1. The total cost of production for chicken powder was calculated in Table 2. On the basis of the above observations cost of one $\mathrm{kg}$ chicken powder was around ₹ 450.30. The equipment cost required during this work is cited in the Table 3 and their annual deprecation was calculated as ₹ 39,250 /Annum on the basis of $10 \%$ annual rate of depreciation. The overhead production cost of $100 \mathrm{~kg}$ product was mentioned in Table 4 which include daily depreciation cost, rent on building per day, labour cost, electricity cost, maintenance cost, water charge and packaging cost, which was estimated around ₹ 2589.08/day.

The formulation cost for $100 \mathrm{~kg}$ product was calculated of all the product groups presented in Table 5. It was found that the cost of production of $100 \mathrm{~kg}$ product for control group ₹ 23,614.25. Cost of production for antioxidant treated group, i.e. for $\mathrm{T}_{1}, \mathrm{~T}_{2}$ and $\mathrm{T}_{3}$ were ₹ 27,835.25, ₹ 24,835.25 and ₹ $27,035.25$ respectively. Per day expenditure cost for $100 \mathrm{~kg}$ product was calculated for all the treated and control group are presented in Table 6. 
Table.1 Cost of formulation of spice mix used in fried snack

\begin{tabular}{|c|c|c|c|c|}
\hline S.No. & Name of ingredients & Quantity (gm) & Rate/kg & Approx. cost \\
\hline 1 & Aniseed (Soanf) & 100 & 125 & 12.2 \\
\hline 2 & Black pepper (Kalimirch) & 200 & 735 & 147 \\
\hline 3 & Capsicum (Mirch powder) & 80 & 160 & 12.8 \\
\hline 4 & Caraway seed (Ajwaen) & 100 & 195 & 19.5 \\
\hline 5 & Cardamom (Bada Elaichi) & 50 & 1360 & 68 \\
\hline 6 & Cinnamon (Dal Chini) & 50 & 180 & 9 \\
\hline 7 & Cloves (Laung) & 30 & 1050 & 31.5 \\
\hline 8 & Coriander powder (Dhaniya) & 170 & 150 & 25.5 \\
\hline 9 & Cumin seed (Jeera) & 100 & 210 & 21 \\
\hline 10 & Mace (Javitri) & 10 & 1050 & 10.50 \\
\hline 11 & Nutmeg (Jaiphal) & 10 & 905 & 9.05 \\
\hline 12 & Dried ginger & 100 & 290 & 29 \\
\hline & Total & \multicolumn{2}{|c|}{1000} & 395.05 \\
\hline
\end{tabular}

Table.2 Cost of production for chicken powder

\begin{tabular}{|c|}
\hline Heads \\
Price of live spent hen \\
\hline Dressing percentage ( $\%)$ \\
\hline Cost of $1 \mathrm{~kg}$ dressed carcass \\
\hline A verage recovery of Deboned meat $(\%)$ \\
\hline Cost of $1 \mathrm{~kg}$ deboned meat \\
\hline Cost of $100 \mathrm{~kg}$ deboned meat \\
\hline Cooking yield of meat powder \\
\hline Cost of meat powder \\
\hline Drying charges \\
\hline Total Cost of $1 \mathrm{~kg}$ meat powder \\
\hline
\end{tabular}

\begin{tabular}{|c|}
\hline Cost \\
\hline $40 / \mathrm{kg}$ \\
65 \\
\hline $40 \times 100 / 65=61.53$ \\
55 \\
\hline $61.53 \times 100 / 55=111.88 / \mathrm{kg}$ \\
\hline $111.88 \times 100=11,188 /-$ \\
\hline $26 \%$ \\
\hline $11,188 / 26=430.30$ \\
\hline $20 /-$ \\
\hline$₹ 450.30$ \\
\hline
\end{tabular}

Table.3 Fixed expenditure (Equipments) cost for fried snack

\begin{tabular}{|c|}
\hline Equipments \\
\hline Meat mincer \\
\hline Steam cooker \\
\hline Freezer (2) \\
\hline Oven (3) \\
\hline Paddle mixer \\
\hline Balance \\
\hline Furniture \\
\hline Grinder \\
\hline Packaging machine \\
\hline Miscellaneous \\
\hline Total fixed expenditure \\
\hline
\end{tabular}

\begin{tabular}{|c|}
\hline Price (in rupee) \\
\hline 60,000 \\
8,000 \\
50,000 \\
$2,25,000$ \\
30,000 \\
1500 \\
6,000 \\
4000 \\
3000 \\
5000 \\
$₹ 3,92,500$ \\
\hline
\end{tabular}


Table.4 The overhead production cost of $100 \mathrm{~kg}$ fried snack

\begin{tabular}{|c|c|c|}
\hline S.No. & Items & Cost (₹) \\
\hline 1 & $\begin{array}{l}\text { Annual depreciation } \\
\text { Daily depreciation cost }\end{array}$ & $\begin{array}{c}\text { @ } 10 \%=₹ 39,250 / \text { Annum } \\
\text { @ } 25 \text { working day=₹ } 109.02 / \text { day }\end{array}$ \\
\hline 2 & $\begin{array}{l}\text { Rent of building } \\
\text { Rent per day }\end{array}$ & $\begin{array}{l}\text { ₹ } 3500 / \text { month } \\
\text { (@ } 25 \text { working days } / \text { month }=₹ 140 / \text { day }\end{array}$ \\
\hline 3 & $\begin{array}{l}\text { Labour cost:- } \\
\text { Trained labour } \\
\text { Untrained labour }\end{array}$ & $\begin{array}{c}\text { @ } ₹ 300(2)=₹ 600 / \text { day } \\
\text { @ ₹ } 250(3)=₹ 750 / \text { day } \\
\text { Total =₹ } 1350 / \text { day }\end{array}$ \\
\hline 4 & Electricity cost & $\begin{array}{c}\text { @ ₹ 8.00/Unit } \\
\text { Total used } 45 \text { unit }=₹ 360 \text { /day }\end{array}$ \\
\hline 5 & Maintenance cost & ₹ 100 /day \\
\hline 6 & Water charge (approx) & ₹ $30 /$ day \\
\hline 7 & Cost of packaging @ ₹ 1.25/Packet & $₹ 500 /$ day \\
\hline & Total & ₹ 2589.08/day \\
\hline
\end{tabular}

Table.5 Formulation cost for $100 \mathrm{~kg}$ fried snack

\begin{tabular}{|c|c|c|c|c|}
\hline \multirow{2}{*}{ Ingredients } & \multicolumn{4}{|c|}{ (in rupees) } \\
\hline Meat powder (30\%) & $\mathbf{C}(\mathbf{F})$ & $\mathbf{T}_{\mathbf{1}}(\mathbf{F})$ & $\mathbf{T}_{\mathbf{2}}(\mathbf{₹})$ & $\mathbf{T}_{\mathbf{3}}(\mathbf{₹})$ \\
\hline Gram flour (70\%) & 13,509 & 13,509 & 13,509 & 13,509 \\
\hline Rosemary (3\%) & 6300 & 6030 & 6030 & 6030 \\
\hline Betel (3\%) & - & 4500 & - & - \\
\hline Rosemary+Betel (1:1) & - & - & 1500 & - \\
\hline Vegetable oil (20\%) & 1800 & - & - & 3700 \\
\hline Spice mix (5\%) & 1975.25 & 19700 & 1800 & 1800 \\
\hline Table salt (1.5\%) & 30 & 30 & 1975.25 & 1975.25 \\
\hline Total & $23,614.25$ & $27,835.25$ & $24,835.25$ & $27,035.25$ \\
\hline
\end{tabular}

Table.6 Per day expenditure for $100 \mathrm{~kg}$ fried snack

\begin{tabular}{|c|}
\hline Groups \\
\hline Rent \\
\hline Depreciation \\
\hline Labor charge \\
\hline Electricity \\
\hline Maintenance \\
\hline Water charge \\
\hline Packaging \\
\hline Total cost of production for $100 \mathrm{~kg}$ \\
formulation \\
\hline
\end{tabular}

\begin{tabular}{|c|c|c|c|}
\hline C (₹) & T1 (₹) & T2 (₹) & T3 (₹) \\
\hline 140 & 140 & 140 & 140 \\
\hline 109 & 109 & 109 & 109 \\
\hline 1350 & 1350 & 1350 & 1350 \\
\hline 360 & 360 & 360 & 360 \\
\hline 100 & 100 & 100 & 100 \\
\hline 30 & 30 & 30 & 30 \\
\hline 500 & 500 & 500 & 500 \\
\hline $26,203.25$ & $30,424.25$ & $27,424.25$ & $29,624.25$ \\
\hline 230 & 267 & 241 & 260 \\
\hline
\end{tabular}

Profit @ 35\%=₹ 94

MRP on the product $=₹ 361$ 
Table.7 Income and total profit from control and rosemary extract (T1), betel extract (T2) and their 1:1 combination (T3) fried snack

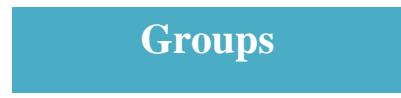

\begin{tabular}{|c|c|c|c|}
\hline C (₹) & T1 (₹) & T2 (₹) & T3 (₹) \\
\hline 131 & 94 & 120 & 101 \\
\hline 13100 & 9400 & 12000 & 10100 \\
\hline 13100 & 9400 & 12000 & 10100 \\
\hline
\end{tabular}

Table.8 Calculation of variable cost and total project cost for control and rosemary extract (T1), betel extract (T2) and their 1:1 combination (T3) fried snack fried snack

\begin{tabular}{|c|c|c|c|}
\hline Groups & Fixed cost $(₹)$ & Variable cost $(₹)$ & Total project cost $(₹)$ \\
\hline $\mathrm{C}$ & $3,92,500$ & $26,203.25$ & $4,18,703.25$ \\
\hline $\mathrm{T}_{1}$ & $3,92,500$ & $30,424.25$ & $4,22,924.25$ \\
\hline $\mathrm{T}_{2}$ & $3,92,500$ & $27,424.25$ & $4,19,924.25$ \\
\hline $\mathrm{T}_{3}$ & $3,92,500$ & $29,624.25$ & $4,22,124.25$ \\
\hline
\end{tabular}

Total project cost $=₹ 500000$

Loan amount $=₹ 425000$

Margin money= $₹ 75,000$

Amount of interest @12\% /annum=₹ 51,000

Amount of loan payment/month=4,250/12 (for 12 months month only)

Amount of loan payment/day $=4,250 / 25=₹ 170$

Table.9 Calculation of break-even point and cost benefit ratio for control and herbal extracts incorporated fried snack

\begin{tabular}{|c|c|c|}
\hline Group & Break Even Point & Cost benefit ratio \\
\hline C & $\begin{array}{c}3,92,500 \times 36,100 / 36,100-26,203.25= \\
14,31,707.37\end{array}$ & $\begin{array}{c}13100 / 26,203.25=0.499 \\
\text { or } 50 \%\end{array}$ \\
\hline $\mathbf{T}_{1}$ & $\begin{array}{c}3,92,500 \times 36,100 / 36,100-30,424.25= \\
24,96,454.21\end{array}$ & $\begin{array}{c}9400 / 26700=0.355 \text { or } \\
35 \%\end{array}$ \\
\hline $\mathrm{T}_{2}$ & $\begin{array}{l}3,92,500 \times 36,100 / 36,100- \\
27,424.25=16,33,154.67\end{array}$ & $\begin{array}{c}12000 / 24,100=0.497 \text { or } \\
50 \%\end{array}$ \\
\hline$\overline{\mathbf{T}_{3}}$ & $\begin{array}{l}3,92,500 \times 36,100 / 36,100- \\
29,624.25=21,88,047.71\end{array}$ & $\begin{array}{c}10100 / 26000=0.388 \text { or } \\
39 \%\end{array}$ \\
\hline
\end{tabular}


Flow diagram for preparation of chicken powder incorporated fried snack

Deboned lean from spent hen

Cut in small cubes

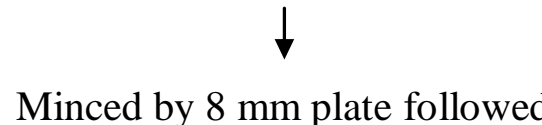

By $4 \mathrm{~mm}$ plate

Boiled in pressure cooker $\left(120^{\circ} \mathrm{C}\right.$ for $\left.15 \mathrm{~min}\right)$

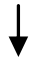

Cooled and dried in Cabinet drier $\left(60^{\circ} \mathrm{C}\right.$ for about 12 hours)

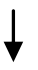

Grinding to powder (chicken powder)

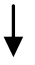

Addition of gram flour, spice mix, seasonings and antioxidants

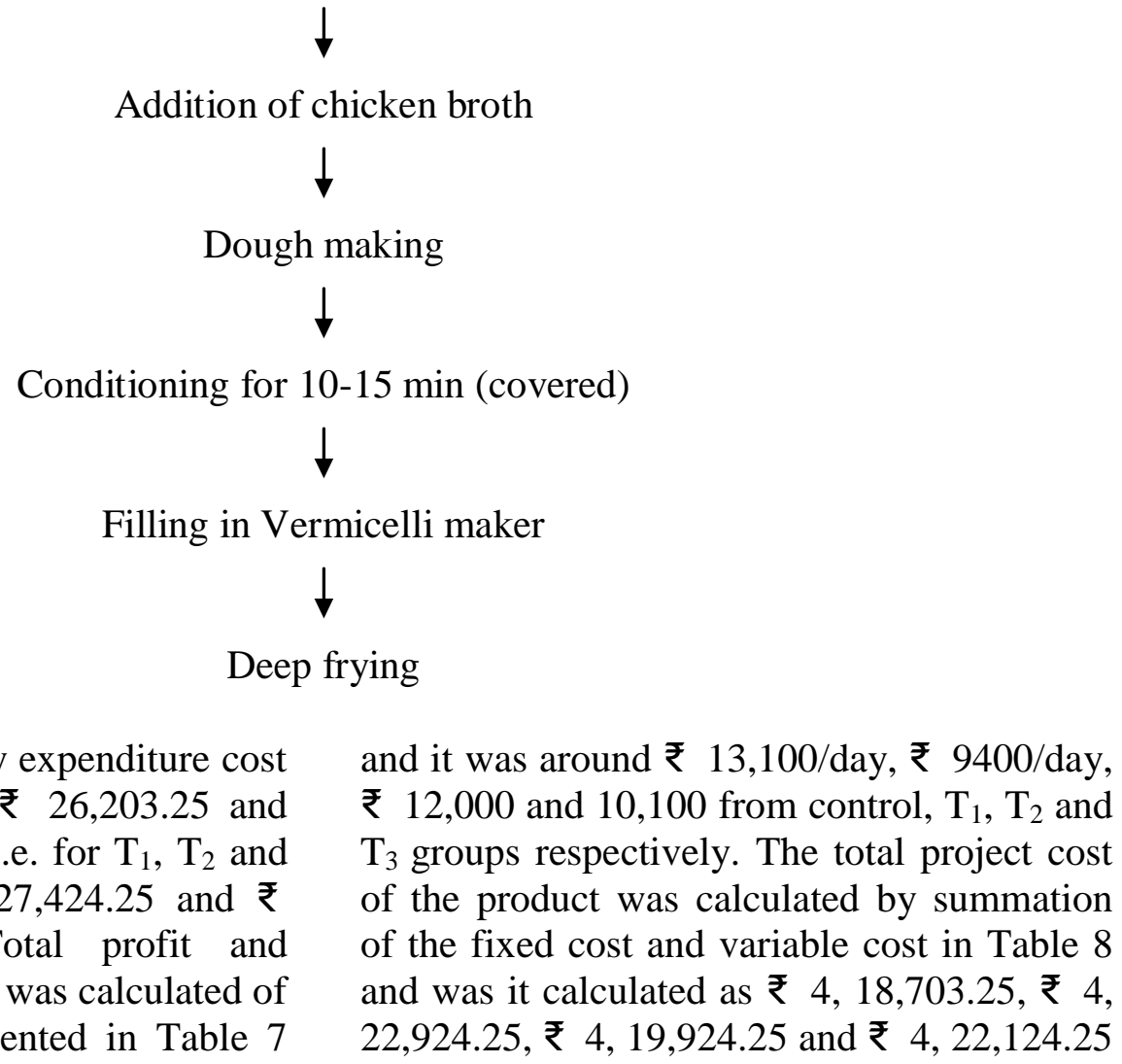


for control, $T_{1}, T_{2}$ and $T_{3}$ groups respectively. The break-even point and cost benefit ratio for control and antioxidant extracts incorporated product was calculated in Table 9 and it was estimated around ₹ $14,31,707.37$ for control, ₹ 24,96,454.21, ₹ 16,33,154.67 and $₹ 21,88,047.71$ for $T_{1}, T_{2}$ and $T_{3}$ groups respectively. The maximum cost benefit ratio was found for control and $\mathrm{T}_{3}$ groups due to lowest formulation cost.

A viable enterprise can be established in tropical countries such as India by keeping rates ₹ 261, ₹ 241, ₹ 260 and ₹ 230 for rosemary extract, betel extract, their $1: 1$ combination incorporated product and control respectively. It can be suggested from the study that the development and adaptation of the technology by the entrepreneurs as a liveness proposal for profitable speculation and hence has an ample opportunity for the employment generations.

\section{Acknowledgment}

The authors thank to RAJUVAS and LPT Department, PGIVER, Jaipur for providing financial support in the form of stipend that contributed a lot for trouble free academic and research work.

\section{References}

BAHS (2014). Basic animal husbandry and fisheries statistics, Government of India, Ministry of agriculture and farmers welfare, Department of animal husbandry.
Bowser TJ, Mwavita M, Al-Sakini A, McGlynn W and Maness NO. 2014. Quality and Shelf Life of Fermented Lamb Meat Sausage with Rosemary Extract. Food Science Journal. 8. 22-31.

FAO 2006. http://faostat.fao.org/faostat Production. Livestock Stock.

Kumar Y, Singh P, Tanwar VK, Ponnusamy P, Singh PK and Shukla P. 2015. Augmentation of quality attributes of chicken tikka prepared from spent hen meat with lemon juice and ginger extract marination. Nutrition \& Food Science. 45(4): 606-615.

Nanditha B and Prabhasankar P. 2008. Antioxidants in Bakery Products: A Review. Food Science and Nutrition. 49(1): 1-27.

Naveena BM, Vaithiyanathan S, Muthukumar M, Sen AR, Kumar Y and Kiran M. 2013. Relationship between the solubility, dosage and antioxidant capacity of carnosic acid in raw and cooked ground buffalo meat patties and chicken patties. Meat Science. 95 (2): 195-202.

Rinzar k, Celan S, Knez Z, Skerget M, Bauman D and Gleasar R. 2006. Antimicrobial and antioxidative activity of rosemary extract in chicken Frankfurters. Journal of food science. 71(7): 425-429.

Talukder S, Mendiratta SK, Soni A, Singh TP, Chhangte L, Kumar RR and Malav OP. 2015. Development and quality characterization of mutton snack. Nutrition \& Food Science. 45 (6): 873882.

\section{How to cite this article:}

Ashish Saini, Anurag Pandey, Sanjita Sharma, Priyanka Meena, Asman Singh Gurjar and Ravi Raman. 2018. Development and Cost Economics of Chicken Powder Incorporated Shelf Stable Fried Snack Prepared from Spent Hen Meat with Rosemary and Betel Leaves Extract. Int.J.Curr.Microbiol.App.Sci. 7(02): 1719-1726. doi: https://doi.org/10.20546/ijcmas.2018.702.208 